\title{
Multivariate principal components analysis of the morphostructural traits of West
} African Dwarf sheep

De Campos ${ }^{1}$, J.S., Ikeobi ${ }^{1}$, C.O.N.*, Olowofeso ${ }^{1}$, O. and Smith $^{2}$, O.F.

${ }^{1}$ Department of Animal Breeding and Genetics. ${ }^{2}$ Department of Animal Physiology. Federal University of Agriculture, P.M.B. 2240, Abeokuta, Nigeria.

*Correspondence Author: ikeobic@yahoo.co.uk

\begin{abstract}
A study was conducted to determine the interdependence among conformation traits of 178 West African Dwarf sheep and to predict body weight from their independent scores using principal components analysis. Body weight and nine morphostructural traits: height at withers, body length, heart girth, rump height, hip width, chest depth, fore canon bone length, tail length, and ear length were measured. Phenotypic correlation coefficients between body weight and body dimensions ranged from 0.78 to 0.79 . Anti-image correlations of the body shape characters showed that partial correlations were low. Two principal components were extracted from the factor analysis with varimax rotation of the inter-correlated traits which accounted for $69.50 \%$ of the total variance. The first principal component (PC1) explained 57.70\% and second principal component (PC2) contributed $11.70 \%$ of the variance. Both PC1 and PC2 could be considered in the selection programme to obtain animals with better conformations using minimal number of measurements.
\end{abstract}

Keywords: Body dimensions, multivariate, principal components analysis, traits, WAD sheep

\section{Introduction}

Morphological traits and body weight are important to access the potentials in West African Dwarf (WAD) sheep, these traits indicates the usefulness of the WAD sheep for commercial production purpose. Researchers have given attention to the body size of livestock animals as the object being observed. Therefore, attempt to measure these traits in a way other than conventional weighing and grading seems appropriate. Multivariate techniques have been greatly applied in animal breeding research. It has been used to access body shape and size in certain animals (Brown et al., 1973; Fumio et al., 1982; Hammock and Shrode, 1986; Yakubu et al., 2009) in cattle, Riva et al. (2004) and Salako (2006) in sheep and goats. Several studies have also been carried out showing a strong correlation between some linear body sizes and production traits, that is linear body size can be used to estimate the body weight of sheep (Otoikhian et al., 2008; Abdel-
Moneim, 2009) and goats (Mukherjee et al., 1981, Adeyinka and Muhammad, 2006; Jimmy et al., 2010).

Analysis of variance and product moment correlations are widely used to characterize phenotypic and genetic relationships among traits in a breeding programme. However, principal components analysis is a valuable refinement for analyzing data on linear body measurements and performance test traits (Dunteman, 1989; Miserani et al., 2002; Posta et al., 2007). Principal components according to Dunteman,(1989); Johnson and Wichern (1998) are linear combinations of all the original set of variables that are estimated in such a way that the first principal component explains the largest percentage of the total phenotypic variance. The first principal component therefore is a measure for the explanation and identification of trait groups which can allow quantitative measurements for animal conformation and enable genetic parameters for these traits to 
be estimated, thereby permitting its inclusion in breeding programmes. Also, according to Morrison (1976), the principal components analysis is a multivariate methodology that can be used with success when characteristics are correlated. This analysis transforms an original group variable into another group principal component which are linear combinations of all the original variables. The main advantage is the independence of these components. From the view point of animal genetics and improvement, principal components simultaneously consider a group of attributes which may be interesting for selection purpose.

The West African Dwarf sheep is one of the breeds of sheep in Nigeria, reared majorly for meat production. However, multivariate techniques have not fully been exploited in the objective description of their body conformations. This present study was therefore designed to document changes in the morphometric traits of WAD sheep and also to explore the relationships among body dimensions using principal component analysis with a view to reducing the number of body measurements required for genetic and breeding purposes. The results so obtained could be used to predict body weight in the field and for selection purpose.

\section{Materials and Methods}

Data used for this study were collected from villages around Odeda agro-ecological zone, Abeokuta, Ogun State, in Southwestern Nigeria. Data were obtained from one hundred and seventy eight $(\mathrm{n}=178)$ randomly selected WAD sheep (consisting 47 rams and 131 ewes) between April and July 2011, reared under the extensive system of management. Animals sampled have age range between 1 and 3 years. Body weight and nine morphometric traits were measured on each animal following the standard procedure and anatomical reference described by Yakubu (2009). The traits measured included: Body length (BL), wither height (WH), heart girth ( $\mathrm{HG})$, chest depth (CD), rump height (RH), hip width (HW), tail length (TL), fore canon bone length (FCB), and ear length (EL) . A graduated measuring steel tape was used for the height measurements, while the length and circumference measurements were done using a flexible tape. In order to avoid intra-individual variations, all the measurements were taken by the same person.

Data collected were subjected to analysis of variance (ANOVA) using a General Linear Model (GLM) procedure of SPSS 2001, mean, standard deviation and coefficient of variation of each measurement were computed. The correlation coefficients of body weight and the linear body measurements were also determined. From the correlation matrix, data for the principal component factor analysis were generated. Barlett's test of sphericity was used to test if the correlation matrix was an identity matrix (each variable correlated with itself) or a correlation matrix full of zero. The suitability of the dataset to principal components analysis (PCA) was further tested by Kaiser-Meyer Olkin (KMO) measures of sampling adequacy. This tested whether the partial correlations among the variables were small. A KMO measure of 0.60 and above is considered adequate (Eyduran et al., 2010).

According to Everitt et al. (2001), PCA is a method for transforming the variables in a multivariate dataset, $X_{1}, X_{2}, \ldots \ldots, X_{p}$, into new variables $Y_{1}, Y_{2}, \ldots \ldots$.. Yp which are uncorrelated with each other and account for decreasing proportions of the total variance of the original variables defined as: 


$$
\begin{aligned}
& y_{1}=a_{11} x_{1}+a_{12} x_{2}+-----------+a_{1 p} \\
& x_{p} y_{2}=a_{21} x_{1}+a_{22} x_{2}+--------+a_{2 p} x_{p} \\
& y_{p}=a_{p 1} x_{1}+a_{p 2} x_{2}+--------+a_{p p} x_{p}
\end{aligned}
$$

with the coefficients being chosen so that $\mathrm{y}_{1}, \mathrm{y}_{2}, \ldots \ldots \ldots \mathrm{y}_{\mathrm{p}}$ account for decreasing proportions of the total variance of the original variables $\mathrm{X}_{1}, \mathrm{X}_{2}, \ldots \ldots \ldots \ldots \mathrm{X}_{\mathrm{p} \text {. }}$

During the evaluation, factors were rotated with varimax rotation of Kaiser. The aim of the varimax rotation is to maximise the sum of the variances of $a_{i j}{ }^{2}$ quadratic weight. The stepwise variable selection of multiple regression procedure was used to obtain models for predicting body weight from body measurements (a) and from established principal components (b):

$$
\begin{aligned}
& \mathrm{BW}=\mathrm{a}+\mathrm{B}_{\mathrm{i}} \mathrm{X}_{\mathrm{i}}+\ldots \ldots \mathrm{B}_{\mathrm{k}} \mathrm{X}_{\mathrm{k}} \ldots \ldots . . . .(\mathrm{a}) \\
& \mathrm{BW}=\mathrm{a}+\mathrm{B}_{\mathrm{i}} \mathrm{PC}_{\mathrm{i}}+\ldots \mathrm{B}_{\mathrm{k}} \mathrm{PC}_{\mathrm{k}} \ldots \ldots \text { (b) }
\end{aligned}
$$

where $\mathrm{BW}$ is the body weight, ' $\mathrm{a}$ ' is the intercept; $B_{1}$ is the $i$-th partial regression coefficient of the i-th linear body measurements, $X_{i}$ or the i-th principal component. The factor programme of SPSS (2001) was used for the analysis.

\section{Results}

The descriptive statistics (means, standard deviations and coefficients of variation of body weight and conformation traits) of WAD sheep are presented in Table 1. It shows the changes in the morphometric traits of the WAD sheep from age one to age three years.

Table 2 presents the anti-image matrices (anti-image correlation) of the linear body measurements of the WAD sheep. Negative relationships existed among the body measurements except for chest depth and fore canon bone length (0.158), hip width and fore canon bone length (0.092), ear length and hip width (0.295), ear length and wither height (0.115), heart girth and wither height (0.077). The highest correlation was between ear length and hip width $(\mathrm{r}=$ 0.295). The anti-image correlations computed showed that partial correlations were low. Kaiser-Meyer-Olkin measures of sampling adequacy computed indicated that the sample sizes were adequate to apply PCA (Kaiser, 1960). Kaiser-Meyer-Olkin measures of sampling adequacy computed for the WAD sheep was 0.886 . The overall significance of the correlation matrices tested with Barlett's Test of sphericity for the body dimensions of the WAD sheep $\left(\chi^{2}=\right.$ 619.296; $\mathrm{P}<0.01)$ provided enough support for the validity of the factor analysis of the dataset. The communalities which stand for the proportion of the variance in the original variables is accounted for by the factor solution and it ranged from 0.761 to 0.767 .

Table 3 shows the total variance, here, principal component 1 (PC1) accounts for $57 \%$ of the variance and principal component 2 (PC2) accounts for $11 \%$ and so on. As expected, the sum of the Eigen value is equal to the number of variables. The Eigen values showed the amount of variance out of the total variance explained by each of the factors. The first factor (5.196) accounts for the most variance and hence has the highest Eigen value, and the next factor (1.056) accounts for much of the leftover variance. The sixth column (\% of variance) has the percentage of total variance accounted for by each factor (i.e. factor 1 accounts for 57.734 and factor 2 accounts for 11.736. The second row shows a value of 69.470 which is the sum of 57.734 and 11.736. Table 4 shows the 
Multivariate principal components analysis of the morphostructural traits of West African Dwarf sheep

Table 1. Descriptive statistics of body measurements of WAD sheep (age 1-3years)

\begin{tabular}{|c|c|c|c|c|c|c|}
\hline Traits & Age & Mean & \pm & $\begin{array}{l}\text { Standard } \\
\text { deviation }\end{array}$ & $\begin{array}{l}\text { Coefficient of } \\
\text { variation }\end{array}$ & $\mathrm{N}$ \\
\hline \multirow[t]{3}{*}{ Body weight (kg) } & 1 & 47.49 & \pm & 3.18 & 6.43 & 26 \\
\hline & 2 & 52.99 & \pm & 5.95 & 11.23 & 47 \\
\hline & 3 & 56.08 & \pm & 3.82 & 6.81 & 66 \\
\hline \multirow[t]{3}{*}{ Body length $(\mathrm{cm})$} & 1 & 11.71 & \pm & 1.43 & 12.21 & 26 \\
\hline & 2 & 54.79 & \pm & 4.22 & 7.70 & 47 \\
\hline & 3 & 58.32 & \pm & 3.58 & 6.14 & 66 \\
\hline \multirow[t]{3}{*}{ Wither height $(\mathrm{cm})$} & 1 & 23.35 & \pm & 2.63 & 11.26 & 26 \\
\hline & 2 & 13.67 & \pm & 1.64 & 11.99 & 47 \\
\hline & 3 & 14.22 & \pm & 1.57 & 11.04 & 66 \\
\hline \multirow[t]{3}{*}{ Rump height (cm) } & 1 & 10.86 & \pm & 1.63 & 15.00 & 26 \\
\hline & 2 & 26.34 & \pm & 2.97 & 11.27 & 47 \\
\hline & 3 & 29.23 & \pm & 3.41 & 11.66 & 66 \\
\hline \multirow[t]{3}{*}{ Fcb length $(\mathrm{cm})$} & 1 & 9.14 & \pm & 1.47 & 16.08 & 26 \\
\hline & 2 & 11.96 & \pm & 2.28 & 19.06 & 47 \\
\hline & 3 & 13.87 & \pm & 1.89 & 13.63 & 66 \\
\hline \multirow[t]{3}{*}{ Chest depth (cm) } & 1 & 52.81 & \pm & 4.83 & 9.15 & 26 \\
\hline & 2 & 10.18 & \pm & 1.35 & 13.26 & 47 \\
\hline & 3 & 10.77 & \pm & 1.71 & 15.87 & 66 \\
\hline \multirow[t]{3}{*}{ Hip width (cm) } & 1 & 19.19 & \pm & 2.29 & 11.93 & 26 \\
\hline & 2 & 59.85 & \pm & 6.97 & 11.65 & 47 \\
\hline & 3 & 68.00 & \pm & 4.87 & 7.16 & 66 \\
\hline \multirow[t]{3}{*}{ Ear length $(\mathrm{cm})$} & 1 & 4.29 & \pm & 0.89 & 20.75 & 26 \\
\hline & 2 & 4.50 & \pm & 1.35 & 30.00 & 47 \\
\hline & 3 & 4.10 & \pm & 0.94 & 22.93 & 66 \\
\hline \multirow[t]{3}{*}{ Heart girth $(\mathrm{cm})$} & 1 & 62.02 & \pm & 5.64 & 9.09 & 26 \\
\hline & 2 & 65.72 & \pm & 7.72 & 11.75 & 47 \\
\hline & 3 & 73.52 & \pm & 7.44 & 10.12 & 66 \\
\hline
\end{tabular}


De Campos, Ikeobi, Olowofeso, and Smith

Table 2. Anti-image matrices of WAD sheep

\begin{tabular}{|c|c|c|c|c|c|c|c|c|c|}
\hline Parameter & $\begin{array}{l}\text { Body } \\
\text { weight }\end{array}$ & $\begin{array}{l}\text { Body } \\
\text { length }\end{array}$ & $\begin{array}{l}\text { Wither } \\
\text { height }\end{array}$ & $\begin{array}{l}\text { Rump } \\
\text { height }\end{array}$ & $\begin{array}{l}\text { Fcb } \\
\text { length }\end{array}$ & $\begin{array}{l}\text { Chest } \\
\text { length }\end{array}$ & $\begin{array}{l}\text { Hip } \\
\text { width }\end{array}$ & $\begin{array}{l}\text { Ear } \\
\text { length }\end{array}$ & $\begin{array}{l}\text { Heart } \\
\text { girth }\end{array}$ \\
\hline $\begin{array}{l}\text { Body } \\
\text { weight (kg) }\end{array}$ & $0.901^{\mathrm{a}}$ & & & & & & & & \\
\hline Body & & $-0.891^{a}$ & & & & & & & \\
\hline length $(\mathrm{cm})$ & -0.176 & & & & & & & & \\
\hline Wither & & & $0.885^{\mathrm{a}}$ & & & & & & \\
\hline height $(\mathrm{cm})$ & -0.081 & -0.183 & & & & & & & \\
\hline Rump & & & & $0.903^{\mathrm{a}}$ & & & & & \\
\hline height (cm) & -0.002 & -0.402 & -0.302 & & & & & & \\
\hline $\begin{array}{l}\text { Fcb length } \\
(\mathrm{cm})\end{array}$ & -0.026 & -0.198 & -0.239 & -0.135 & $\begin{array}{l}-0.760 \\
\mathrm{a}\end{array}$ & & & & \\
\hline $\begin{array}{l}\text { Chest depth } \\
\text { (cm) }\end{array}$ & -0.106 & -0.140 & -0.315 & -0.129 & 0.158 & $0.904^{\mathrm{a}}$ & & & \\
\hline $\begin{array}{l}\text { Hip width } \\
(\mathrm{cm})\end{array}$ & -0.193 & -0.082 & 0.018 & -0.162 & 0.092 & -0.119 & $\begin{array}{l}0.893 \\
\text { a }\end{array}$ & & \\
\hline $\begin{array}{l}\text { Ear length } \\
(\mathrm{cm})\end{array}$ & -0.257 & -0.138 & 0.115 & -0.081 & -0.219 & -0.084 & 0.295 & $\begin{array}{l}0.839 \\
\mathrm{a}\end{array}$ & \\
\hline $\begin{array}{l}\text { Heart Girth } \\
(\mathrm{cm})\end{array}$ & -0.424 & -0.180 & 0.077 & -0.068 & -0.232 & -0.178 & $\begin{array}{l}- \\
0.234\end{array}$ & -0.084 & $0.892^{\mathrm{a}}$ \\
\hline
\end{tabular}

component matrix made up of $\mathrm{PC} 1$ and PC2. Each number represents the quantification of the body measurements and the unrotated factor. For example, the quantification of body weight and $\mathrm{PC} 1$ was 0.872 , while that of heart girth and PC1 was 0.876 which was the highest quantification value observed and this implies that $\mathrm{PC} 1$ has a high significant quantification with majority of the traits observed body weight $(0.872)$, body length $(0.840)$, wither height (0.781), rump height (0.869), chest depth
(0.742), hip width (0.707) and heart girth (0.876); implying that there is a high quantification in the variables.

Table 5 provides the model summary which gives the simple correlation $(\mathrm{R})$ and $\mathrm{R}^{2}$ value which describes how much of the dependent variable (body weight) can be explained by the independent variable (heart girth). Table 6 described the coefficients of the variables which gives information on each predictor variable. This provides the information necessary to

Table 3. Total variance of each component showing the percentage of variance and cumulative percentage

\begin{tabular}{|c|c|c|c|c|c|c|c|c|c|}
\hline & \multicolumn{3}{|c|}{ Initial Eigen values } & \multicolumn{3}{|c|}{$\begin{array}{l}\text { Extraction sums of squared } \\
\text { loadings }\end{array}$} & \multicolumn{3}{|c|}{ Rotation } \\
\hline Component & Total & $\begin{array}{l}\% \text { of } \\
\text { variance }\end{array}$ & $\begin{array}{l}\text { Cumulative } \\
\%\end{array}$ & Total & $\begin{array}{l}\% \text { of } \\
\text { variance }\end{array}$ & $\begin{array}{l}\text { Cumulative } \\
\%\end{array}$ & Total & $\begin{array}{l}\% \text { of } \\
\text { variance }\end{array}$ & $\begin{array}{l}\text { Cumulative } \\
\%\end{array}$ \\
\hline 1 & 5.196 & 57.734 & 57.734 & 5.196 & 57.734 & 57.734 & 4.394 & 48.823 & 48.823 \\
\hline 2 & 1.056 & 11.736 & 69.470 & 1.056 & 11.736 & 69.470 & 1.858 & 20.647 & 69.470 \\
\hline 3 & 0.703 & 7.815 & 77.285 & 0.703 & 7.815 & 77.285 & 0.703 & 7.851 & 77.285 \\
\hline 4 & 0.574 & 6.382 & 83.667 & 0.574 & 6.382 & 83.667 & 0.574 & 6.382 & 83.667 \\
\hline 5 & 0.509 & 5.656 & 89.323 & 0.509 & 5.656 & 89.323 & 0.509 & 5.656 & 89.323 \\
\hline 6 & 0.307 & 3.410 & 92.733 & 0.307 & 3.410 & 92.733 & 0.307 & 3.410 & 92.733 \\
\hline 7 & 0.271 & 3.006 & 95.739 & 0.271 & 3.006 & 95.739 & 0.271 & 3.006 & 95.739 \\
\hline 8 & 0.200 & 2.227 & 97.966 & 0.200 & 2.227 & 97.966 & 0.200 & 2.227 & 97.966 \\
\hline 9 & 0.183 & 2.034 & 100.000 & 0.183 & 2.034 & 100.00 & 0.183 & 2.034 & 100.000 \\
\hline
\end{tabular}


Table 4. Component matrix

\begin{tabular}{lcc}
\hline & \multicolumn{2}{l}{ Component } \\
Parameter & 1 & 2 \\
\hline Body weight $(\mathrm{kg})$ & 0.872 & -0.027 \\
Body length (cm) & 0.840 & -0.106 \\
$\begin{array}{l}\text { Wither height } \\
(\mathrm{cm})\end{array}$ & 0.781 & -0.022 \\
$\begin{array}{l}\text { Rump height } \\
(\mathrm{cm})\end{array}$ & 0.869 & -0.043 \\
$\begin{array}{l}\text { Fore canon bone } \\
\text { length }(\mathrm{cm})\end{array}$ & 0.455 & 0.706 \\
$\begin{array}{l}\text { Chest depth (cm) } \\
\text { Hip width }(\mathrm{cm})\end{array}$ & 0.742 & -0.201 \\
Ear length $(\mathrm{cm})$ & 0.707 & -0.452 \\
Heart girth $(\mathrm{cm})$ & 0.585 & 0.546 \\
\hline
\end{tabular}

predict body weight from heart girth and other body measurements and they also contribute significantly to the models.

\section{Discussion}

The positive and significant correlation among the body measurements indicates a high predictability among the variables (Pundir et al., 2011). The anti-image correlations computed showed that partial correlations were low, indicating that true factors existed in the data. This is buttressed by Kaiser-Meyer Olkin measure of sampling adequacy studied from the diagonal of partial correlation, revealing the proportion of the variance in the body measurements caused by the underlying factor of 0.886 . The overall significance of the correlation matrices tested with Barlett's Test of sphericity for the body dimensions of the WAD sheep $\left(\chi^{2}=\right.$ $619.269, \mathrm{P}<0.01)$ provided enough support for the validity of the factor analysis of the dataset. After the varimax rotation, most of the variables that measured the linear body dimensions (body length, wither height, rump height, chest depth, hip width and heart girth) were highly significantly correlated. This is because the factors were extracted successfully and they accounted for gradual reduction in the overall variance. These findings are in consonance with the observations of Shahin and Hassan (2001) in their studies with New Zealand White rabbits. Similarly, Shahin et al. (1993) reported for Egyptian buffalo that the first factor was characterised by high positive loadings on all body shape characters, the variables associated with body length had the highest loading followed by heart girth and abdominal girth. It also corroborates the earlier submission of Salako (2006) that the first principal component comprising seven measurements (foreleg length, tail length, face length, rump height, withers height, body length and heart girth) explained $67.7 \%$ of the generalised variance and can be considered as a generalised size factor. Similarly, results of this study were consistent with those reported by McCracken et al. (2000) in ducks, and in

Table 5. Model summary*

\begin{tabular}{|c|c|c|c|c|}
\hline Model & $\mathrm{R}$ & $\mathrm{R}^{2}$ & Adjusted $\mathrm{R}^{2}$ & Standard error of the estimate \\
\hline 1 & 0.803 & 0.645 & 0.642 & 3.863 \\
\hline 2 & 0.828 & 0.686 & 0.681 & 3.646 \\
\hline 3 & 0.837 & 0.701 & 0.693 & 3.577 \\
\hline 4 & 0.847 & 0.717 & 0.706 & 3.496 \\
\hline
\end{tabular}

* 1 = Predictor: (constant), heart girth, 2 = Predictors: (constant), heart girth, body length, $3=$ Predictors: (constant), heart girth, body length, ear length, 4 = Predictors: (constant), heart girth, body length, ear length, hip width and $\mathrm{R}=$ Regression value. 
De Campos, Ikeobi, Olowofeso, and Smith

Table 6: Coefficients of the variables

\begin{tabular}{|c|c|c|c|c|c|c|}
\hline \multirow{2}{*}{\multicolumn{2}{|c|}{ Model }} & \multicolumn{2}{|c|}{ Unstandardized Coefficients } & \multicolumn{3}{|c|}{ Standardized Coefficients } \\
\hline & & $\mathrm{B}$ & Std. Error & Beta $t$ & & Sig. \\
\hline \multirow[t]{2}{*}{1} & (Constant) & -24.712 & 2.727 & & -9.060 & .000 \\
\hline & heart girth & .728 & .051 & .803 & 14.256 & .000 \\
\hline \multirow[t]{3}{*}{2} & (Constant) & -26.586 & 2.621 & & -10.144 & .000 \\
\hline & heart girth & .549 & .067 & .605 & 8.158 & .000 \\
\hline & $\begin{array}{l}\text { body } \\
\text { length. }\end{array}$ & .200 & .052 & .284 & 3.832 & .000 \\
\hline \multirow[t]{4}{*}{3} & (Constant) & -28.691 & 2.728 & & -10.519 & .000 \\
\hline & heart girth & .506 & .068 & .558 & 7.388 & .000 \\
\hline & $\begin{array}{l}\text { body } \\
\text { length. }\end{array}$ & .178 & .052 & .253 & 3.416 & .001 \\
\hline & ear length & .623 & .270 & .141 & 2.311 & .023 \\
\hline \multirow[t]{5}{*}{4} & (Constant) & -29.055 & 2.670 & & -10.884 & .000 \\
\hline & heart girth & .422 & .075 & .465 & 5.619 & .000 \\
\hline & $\begin{array}{l}\text { body } \\
\text { length. }\end{array}$ & .142 & .053 & .202 & 2.681 & .008 \\
\hline & ear length & .801 & .273 & .181 & 2.934 & .004 \\
\hline & hip width & .510 & .205 & .173 & 2.487 & .014 \\
\hline
\end{tabular}

Dependent variable: body weight

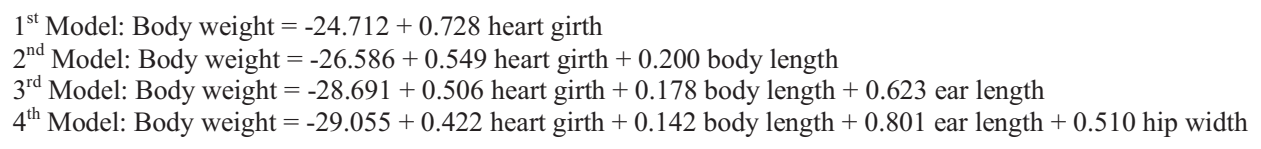

ruminants by (Yakubu, 2009; Yakubu et al., 2009) where PC1 was termed the overall body size. Similarly, Kashiwamura et al. (2001) reported that the first factor accounted for the largest variance in horses. The principal component could be important in evaluating animals for breeding and selection purposes. Both principal components extracted could play a role in the ranking of the animals and thus provide an opportunity to select the animals based on a group of variables rather than on isolated traits. Gusmao-Filho et al. (2009), extracted five principal components from eleven original traits and concluded that these could be of great importance in the determination of body attributes of sheep for both reproduction and meat production.

The interdependent original body measurements or conformation traits and their independent principal component scores were used to predict body weight of sheep. The results of the stepwise multiple regression analysis revealed that heart girth 
was the single variable of utmost importance in the prediction of body weight. Heart girth alone explained about $64 \%$ of the variation in body weight. When body length was added to the model, the proportion of explained variance increased to $68 \%$. The combination of heart girth, body length and ear length accounted for about $70 \%$. This result indicates that body weight can be predicted with a fair degree of accuracy from body dimensions. Similar findings of this nature have been reported by (Yakubu, 2009; Yakubu et al., 2009). However, the use of body measurements to predict body weight or growth should be treated with caution due to multicollinearity which has been shown to be associated with unstable regression estimates (Ibe,1989), thereby leading to unreliable predictions. This justifies the use of indices of the body measurements referred to as principal components for prediction, since they are orthogonal to each other.

\section{Conclusion}

In WAD sheep and according to the results of this study, PC1 had the largest share of the total variance and correlated highly with body length, wither height, rump height, heart girth, chest depth and hip width. These highly correlated traits and the use of orthogonal body shape characters (PC1 and PC2) could be used to predict the body weight of the WAD sheep, which could be more reliable when compared to the original inter-correlated body measurements. Multiple collinearity of interdependent explanatory variables could result in erroneous conclusions when original body measurements are used as predictors. The PC2 was orthogonal to PC1 and loaded heavily on the fore canon bone length. The multivariate principal component analysis technique was also used to consolidate and describe the interdependence (general size and body indices) of WAD sheep. This method of analysis can therefore be applied in the ranking of animals based on different indices thus aiding in the drastic reduction of the number of body measurements required for selection in a breeding programme for improvement and performance of the WAD sheep.

\section{References}

Abdel-Moneim, A. Y. 2009. Use of live body measurements for prediction of body and carcass cuts weights in three Egyptian breeds of sheep. Egyptian Journal of Sheep and Goat Science. 2: 17-32.

Adeyinka, I. A. and Mohammed, I. D. 2006. Relationship of live weight and linear body measurement in two breeds of goat of northern Nigeria. Journal of Animal and Veterinary Advances. 11: 891-893.

Brown, C. J., Brown, J. E. and Butts, W. T. 1973. Evaluating the relationship among immature measure of size, shape and performance of beef bulls and the relationships between immature measures of size shape and feedlot traits in young bulls. Journal of Animal Science. 36: 10-21.

Carpenter, J. A., Fitzhugh, H. A., Cartwright, T. C., Meltton, A. A. and Thomas, R. C. 1971. Principal component for size of Hereford cows. Journal of Animal Science. 33: 197199.

Dunteman, G. H. 1989. Principal components analysis. Sage University paper series on quantitative applications in Social Sciences, 07-069. Thousand Oaks, California, USA, Sage Publications 
Inc.

Everitt, B. S., Landau, S. and Leese, M. 2001. Cluster Analysis. $4^{\text {th }}$ Edition, Arnold Publisher, London.

Eyduran, E., Topal, M. and Sonmez, A. Y. 2010. Use of factor scores in multiple regression analysis for estimation of body weight by several body measurements in brown trouts (Salmo trutta fario). International Journal of Agriculture and Biology. 12: 611615.

Fumio, M., Hideaki, N. and Toyokazu, F. 1982. Application of principal component analysis for defining size and shape in Japanese black cattle sires. The Science reports of Faculty of Agriculture, Kobe University, 15: 169-176.

Gusmao-Filho, J. D., Teodoro, S. M., Chaves, M. A. and Oliveira, S. S. 2009. Factorial analysis of morphometric measurements in Santa Ines like ovines. Archivos de Zootecnia 222: 289-292.

Hammock, S. P. and Shrode, R. R. 1986. Calf-hood weights, body measurements and measures of fatness versus criteria of overall size and shape for predicting yearling performance in beef cattle. Journal of Animal Science. 63:447-452.

Ibe, S. N. 1989. Measures of size and conformation in commercial broilers. Journal of Animal Breeding and Genetics. 106: 461-469.

Jimmy, S., David, M., Donald, K. R. and Dennis, M. 2010. Variability in body morphometric measurements and their application in predicting live body weight of Mubende and Small East African goat breeds in Uganda. Middle-East Journal of Scientific Research. 2: 98-105.

Johnson, R. A. and Wichern, D. W. 1998.
Applied multivariate statistical analysis. 5th Edition, Practice Hall. Texas.

Kashiwamura, F., Avgaandorj, A. and Furumura, K. 2001. Relationship among body size, conformation and racing performance in Banei draft racehorses. Journal of Equine Science. 12: 1-7.

McCracken, K. V., Paton, D. C. and Afton, A. D. 2000. Sexual size dimorphism of the Musk duck. Wilson Bulletin. 112:457-466.

Miserani, M. G., McManus, C., Santos, S. A., Silva, J. A., Mariante, A. S., Abreu, U. G. P., Mazza, M. C. and Sereno, J. R. B. 2002. Variance analysis for biometric measures of the Pantaneiro horse in Brazil. Archivos Zootecnia. 51: 113-120.

Morrison, D. F. 1976. Multivariate statistical methods. McGraw-Hill Company, New York.

Mukherjee, D. K., Singh, S. K. and Mishra, H. R. 1981. Phenotypic correlations of body weight with body measurements in Grey Bengal goats. Indian Journal of Animal Science. 51: 682-694.

Otoikhian, C. S. O., Otoikhian, A. M., A kporhuarho, O. P. and Isidahomen, C. 2008. Correlation of body weight and some body measurement parameters in Ouda sheep under extensive management system. African Journal of Genetics and Agriculture. 3: 129-133.

Posta, J., Komlosi, I. and Mihok, S. 2007. Principal component analysis of performance test traits in Hungarian sporthorse mares. Arch Tierzucht Dummerstorf. 50: 125-135.

Pundir, R. K., Singh, P. K. and Dangi, P. S. 2011. Factor analysis of biometric traits of Kankrej cows to explain body 
Multivariate principal components analysis of the morphostructural traits of West African Dwarf sheep

conformation. Asian-Australasian Journal of Animal Science. 24: 449456.

Riva, J., Rizzi, R., Marelli, S. and Cavalchini, L. G. 2004. Body measurements in Bargamasca sheep. Small Ruminant Research. 55: 221227.

Salako, A. E. 2006. Principal component factor analysis of the morphostructure of immature Uda sheep. International Journal of Morphology. 24: 571-574.

Shahin, K. A. and Hassan, N. S. 2000. Sources of shared variability among body shape characters at marketing age in New Zealand White and Egyptian rabbit breeds. Annal of
Zootechnology. 49: 435-45.

Shahin, K. A., Soliman, A. M., and Moukhtar, A. E. 1993. Sources of shared variability for the Egyptian buffalo body shape (conformation). Livestock Production Science. 36: 323-334.

SPSS. 2001. Statistical Package for Social Sciences. Chicago, SPSS Inc., 444 Michigan Avenue, IL60611

Yakubu, A., Ogah, D. M., and Idahor, K. O. 2009. Principal component analysis of the morpho-structural indices of White Fulani cattle. Trakia Journal of Science. 7: 67-73.

Received: $3^{\text {rd }}$ January, 2014

Accepted: $1^{\text {th }}$ September, 2015 